\title{
THE GEOLOGIST.
}

\author{
JANUARY, 1861.
}

H I GH A N D L O W L IF E.

By Georae E. Roberts.

OUR knowledge of the limits of animal life have been notably extended during the year which has just departed. Air, blown upon an adhesive surface by the aeroscope on the summit of Etna, twelve thousand feet above the sea level, has been found to contain large quantities of Diatomaces; and thus the presence of a zone of life has been discovered to us, soaring not only above the limits hitherto fixed, but above the range of physical phenomena in the mountain itself.

And now the ocean-depths have given up a secret as marvellous. We are taught that at a depth below the surface nearly as great as the height of the infusorial zone above it, animals as high in the scale of being as starfishes are enjoying life. The one discovery is a fitting pendant to the other, and yet, how great is their difference! In the one case the extreme rarification of the atmosphere seemed to our notions to render life impossible; in the other, the enormous pressure of the opposite element, which in the homes of these starfishes must amount to at least a ton and a-half on the square inch, is so greatly at variance with our belief, that we are confounded at the very outset of the inquiry. The capability in an animal so well accustomed to air as the starfish-whose ordinary domain is the seabeach-to exist without it, and its inherent power of withstanding a

voL. IV. 
pressure that would upon the surface grind a rock to powder, are studies replete with instruction and value-studies which can be turned to a good geologieal account, and made to bear reference to a past fauna as well as to a living one. I will attempt, therefore, to give an abstract of the valuable contribution to our knowledge of animal life in deep sea-zones, which contains the important discovery I allude to; ; for as the pamphlet is printed "for private circulation," it is only attainable by the few. In it the author not only gives us in one view a resumé of our present data upon the subject, but a series of notes which point, with no uncertain finger, to a great extension of them.

Dr. Wallich's zoological labours while on duty entitle him to rank as no mean associate of the great naturalists to whom he gracefully dedicates his notes; and the modest way in which he introduces a strong foundation for a most important inquiry, proves that he looks upon scientific experience

\footnotetext{
"As an arch wherethro"

Gleams that untravell'd world, whose margin fades

For ever and for ever when I move."
}

In sounding not quite midway between Cape Farewell and Rockall, at a point east of Iceland, and in one thousand two hundred and sixty fathoms of water, the sounding apparatus brought up an ample specimen of coarse gritty-looking ooze, containing about ninety-five per cent. of Globigerina-shells (an important genus of the Foraminifera); while adherent to the lowest fifty fathoms of the line, a number of starfishes, belonging to the genus $O_{p}$ hiocoma, came up. They had attached themselves while this part of the line, which had been paid out in excess of the depth, rested upon the bottom, not at all calculating what an upward journey their investigations would cost them, and what a greeting they would receive. They continued to move freely about for a quarter of an hour after their introduction into human society, and from the naturalist and his wondering

* "Notes on the Presence of Animal Life at Vast Depths in the Sea ; with Observations on the Nature of the Sea-bed as bearing on Submarine Telegraphy." By G. C. Wallich, M.D., F.L.S., \&c.; naturalist to the expedition despatched in 1860, under the command of Sir Leopold M'Clintock, to survey the proposed North Atlantic telegraph route between Great Britain and America. 1860. 
friends the illustrious strangers received every courtesy and attention. But, as may be supposed, they were too precions to be returned to the deep-sea home they had left, even supposing they could have got there; so were put in spirits, and consigned to an immortality they little expected. One fine fellow, who clung convulsively to the rope, was secured in situ, and is now a "lion" of scientific London.

"Here, then," says our author, "is a fresh starting-point in the natural history of the sea. At a depth of nearly two miles below the surface, where it is difficult to believe the most attenuated ray of light can penetrate, we find a highly organized species of radiate animal living, and evidently flourishing; its red and light-pinkcoloured tints as clear and brilliant as those seen in its congeners who live where the sun's rays can penetrate freely. Differing in no respect of internal anatomy from the species of Ophiocomoe inhabiting shallow water, and evidencing, by their freedom of life and action, that circulation of sea-water, digestion, assimilation, and reproduction were carried on in their frames, unrestricted by the obstacles enumerated, in addition to the simpler but no less essential operations of locomotion and captare of food." In the alimentary cavity numerous Globigerina-shells were found, more or less freed from their soft sarcodal contents.

Now the Ophiuridø, to which division of star-fishes Ophiocoma belongs, differ from what are usually called true star-fishes of the wellknown stellate or angular forms, by the absence of protrusile suckers as organs for effecting motion; the want being in them supplied by spine-covered arms, from which they derive the name of "spinigrada." They have no power whatever of raising themselves from the bottom, or of travelling in other fashion than as creeping, crawling animals. Moreover, Professor E. Forbes has told us in his "Monograph on the British Starfishes," that the Ophiuridx is a more local family than starfishes proper, and more affected by climatal causes. So that, though the discovery of any starfish under the circumstances is wonderful enough, the marvel is increased tenfold by its being a Spinigrade form; for as the point of capture was five hundred miles from Greenland, and two hundred and fifty from Iceland-Cape Farewell in the former, and the "Blinde Skier" 
rocks in the latter being respectively the nearest land-it is impossible they could have been a chance drift, borne along by a current from either country. "Therefore," says Dr. Wallich, "all former opinion as to the limit of life in the deep sea must give place to such a startling fact. And where one form so highly organised has been met with, it is only reasonable to assume that other correlated forms may also exist; and we may look forward to the discovery, at no very distant period, of a new submarine fauna, frequenting the deeper fastnesses of the ocean, which, while furnishing a new field of research for those who are content to seek after living novelties, shall also throw a gleam of light on the geology and palæontology of the globe."

Respecting the Globigerina, those minute Foraminifera whose shells constitute so large a proportion of the " oozy" deposits brought up by mid-Atlantic soundings, one interesting subject of debate has been set at rest by Dr. Wallich's discoveries. They do exist in a living state at great depths, though the signs of life apparent in them when examined after an hour's upward travel from the seabottom to the surface, were feebler than in those taken from beneath shallow water. Indeed, irrespective of the experiments by which the author arrived at this conclusion, the circumstances of their having been detected in the digestive cavity of one of the starfishes makes it highly probable that they form their chief source of food.

In sereral samples of Globigerina ooze, the minute cell-like bodies provisionally called "Coccoliths" by Prof. Huxley were detected, looking at first sight very like the cells of the algal plant Protococcus (now shown to be an abnormal development of lichen-gonidia); those Dr. Wallich considers may probably be the larvo of the Globigerince. They appeared in two states, as globules adherent to the surface of cellular mycelia, and as free moving bodies, showing in some instances the commencement of cell-division. Their discovery in a living state in this oose is of high geological importance; for microscopical investigation, undertaken by $\mathrm{Mr}$. Sorby, proves their existence in chalk-rocks, associated there, as they are in this North Atlantic ocean, with Globigerince. Indeed, chalk itself is seen to be little else than a compacted mass of Foraminifera shells, whole and fragmentary, and may be best described by using the very words by 
which Dr. Wallich introduces to science the recent deposit. Light from discoveries of to-day is thus thrown backward, and thus finds reflection in analogous conditions of deep-sea deposits and buried animal-life at a remote geological period, which in turn aids us in investigating present life, and proves that conditions favourable to Foraminifera-life could support Radiata, Echinodermata, and Mollusca, which, could we dredge as well as sound in the deep Atlantic, would doubtless reward our search.

As yet, no companions to the Ophiocomoe and Globigerino have been taken from the enormous depth at which these forms of life exist, but a living Serpula was obtained from a sounding of six hundred and eighty fathoms, in conjunction with a living Spirorbis. Other free Annelids, and two amphipod Crustaceans, were also taken alive at four hundred and forty-five fathoms; depths, be it remembered, far beyond any previously-known habitat.

Some remarkable phenomena connected with atmospheric influences are noticed by Dr. Wallich during his cruise, such as the almost entire absence of those varied forms of animal life which usually present themselves upon the surface, such as Pteropods. This he attributes to the severity of the past season, which appeared to have exercised such an influence upon surface-water life, that even Diatomaces were scantily represented. And another matter worthy of note was the scarcity of drift-timber, in ordinary years borne along by the deflection of the Gulf-stream, and cast upon the coast of Greenland. This our learned author advisedly regards as a proof of a variation in the course of the Gulf-stream proper, before it was caught up and deflected by the Arctic current; or, what is still more probable, that this year has been marked by an extension of the Arctic current, sufficiently great to overpower and deflect the Gulfstream, bear down its floating burden to other lands, and materially lower the temperature of Northern Europe.

Some sensible hints as to the surveying of the sea-bottom beneath deep water are given by our author; and he suggests, with a kindly feeling towards further investigators, a sensible method of procuring Diatomaceæ, Polycystinew, \&c., from sea-water, which being quite new, and likely to turn many good things into the hands of those who study these tiny but most important organisms, I am glad to in- 
clude in my abstract. When the boilers of steam-ships are being cleaned, procure portions of the calcareous deposits scaled off the interior, and by treating them in the usual way with nitro-muriatic acid, Diatomacean-forms and Polycystina-shells may be detected in considerable quantity.

By obtaining these deposits from ships plying within known limits, a series of free floating Diatomacees might be secured which would afford good data for the ascertainment of their range, distribution, and limits. And so, heartily thanking Dr. Wallich for this crumb of friendly feeling, I close his pamphlet. The year that has just departed has thrown no light of equal importance on geological history; though it has been a very notable year in geological sciencenotable in the importance of its discoveries, thoughtfully made, and carefully introduced; and beyond measure notable in its crop of theories, and in the agitations produced by them. But of these latter "helps to knowledge" we have surely had enough. Dr. Wallich has sent the ball rolling in another direction; and his labours are more clearly reflected in the mirror of Truth than is any attempt to claim creative power for the working of secondary principles.

\section{A CHRISTMAS LECTURE ON "COAL"}

By J. W. SAlter, F.G.S.

Nor a great many years ago the "bigwigs" in England were assembled in conclave, and the élite of science was called before them. There were a great many lumps of a blackish-brown substance on the table, and a great deal of smelling, and burning, and poking of the same black lumps by the same "bigwigs" and learned men. It was the great "Torbane Hill Coal" case.

"The point was in question, as all the world knows,

To what the said substances ought to belong."

Was it pure carbon? Was it carbonaceous shale? Was it shale without much carbon? Was it carbon without much shale? Was it bituminous shale? Was it coal-shale? Was it cannel? Was it coal?

We are afraid to say how many guineas were spent, or how many microscopes were busy in London and Edinburgh. But after all 